\title{
Free movement and equal treatment in an unequal union
}

Schmidt, Susanne K; Blauberger, Michael; Martinsen, Dorte Sindbjerg

Published in:

Journal of European Public Policy

DOI:

10.1080/13501763.2018.1488887

Publication date:

2018

Document version

Publisher's PDF, also known as Version of record

Citation for published version (APA):

Schmidt, S. K., Blauberger, M., \& Martinsen, D. S. (2018). Free movement and equal treatment in an unequal union. Journal of European Public Policy, 25(10), 1391-1402. https://doi.org/10.1080/13501763.2018.1488887 


\section{Journal of European Public Policy}

ISSN: 1350-1763 (Print) 1466-4429 (Online) Journal homepage: http://www.tandfonline.com/loi/rjpp20

\section{Free movement and equal treatment in an unequal union}

\section{Susanne K. Schmidt, Michael Blauberger \& Dorte Sindbjerg Martinsen}

To cite this article: Susanne K. Schmidt, Michael Blauberger \& Dorte Sindbjerg Martinsen (2018) Free movement and equal treatment in an unequal union, Journal of European Public Policy, 25:10, 1391-1402, DOI: 10.1080/13501763.2018.1488887

To link to this article: https://doi.org/10.1080/13501763.2018.1488887
(c) 2018 The Author(s). Published by Informa UK Limited, trading as Taylor \& Francis Group

Published online: 23 Aug 2018.

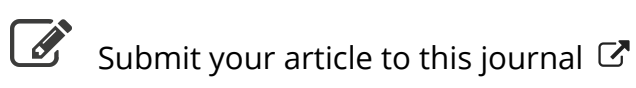

Џ Article views: 153

View Crossmark data \lceil 


\title{
Free movement and equal treatment in an unequal union
}

\author{
Susanne K. Schmidt ${ }^{\mathrm{a}}$, Michael Blauberger ${ }^{\mathrm{b}}$ and Dorte Sindbjerg Martinsen ${ }^{\mathrm{c}}$

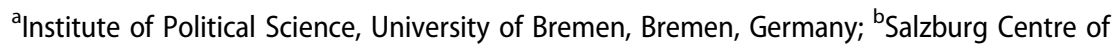 \\ European Union Studies (SCEUS), University of Salzburg, Salzburg, Austria; 'Department of \\ Political Science, University of Copenhagen, Copenhagen, Denmark
}

\begin{abstract}
The European Union's (EU) fundamental principles of free movement of persons and non-discrimination have long challenged the traditional closure of the welfare state. Whereas the relationship between the EU and the welfare state appeared largely reconciled before the grand enlargement of 2004, economic downturn and politicisation question the nexus anew. This collection explores the current dynamics, scope and limits of free movement and welfare equal treatment for EU citizens on the move. The different contributions bring together the normative, legal and political developments and about-turns which dynamically square the circle of pan-European social solidarity. The collection covers the new politics of EU cross-border welfare but also the structuring role of the European Court of Justice. It includes the political economy of free movement as well as its outputs and outcomes in selected member states. Finally, it analyses the mechanisms that activate attitudinal polarisation on intra-EU migration and welfare.
\end{abstract}

KEYWORDS European citizenship; European court of justice; free movement; migration; politicisation; welfare states

\section{Introduction}

The free movement of workers is a cornerstone of European integration. Over time, it has been extended to EU citizens more generally and infused with equal treatment rights. Yet, equal treatment and free movement itself have come under challenge. Since Eastern enlargement and particularly after Bulgaria and Romania reached full free movement rights in 2014, the potential of welfare migration is contentiously discussed. In the Brexit referendum, the issues of exempting recently settled EU citizens from social benefits or even limiting their settlement fared high. While the British situation was unique, the potential of politicisation of free movement rights is evident. In

CONTACT Michael Blauberger michael.blauberger@sbg.ac.at

(c) 2018 The Author(s). Published by Informa UK Limited, trading as Taylor \& Francis Group

This is an Open Access article distributed under the terms of the Creative Commons Attribution-NonCommercial-NoDerivatives License (http://creativecommons.org/licenses/by-nc-nd/4.0/), which permits non-commercial re-use, distribution, and reproduction in any medium, provided the original work is properly cited, and is not altered, transformed, or built upon in any way. 
fact, the European Union is exceptional among all regional organisations in granting wide-ranging free movement rights among its member states, and this in a context where some of the member states have the most developed welfare states worldwide. Geddes and Hadj-Abdou describe it as 'a radical experiment in open borders (...) uneasily coupled with a continued attachment in member states to social solidarity and cohesion associated with national welfare states' (Geddes and Hadj-Abdou 2016: 222). This experiment takes place in a political system with a manifest status-quo bias in its policymaking, backed by a high degree of judicialisation of decision-making, while facing increased politicisation and economic heterogeneity.

Due to enlargement and economic crises that are fuelled by the uneven working of the Euro-regime, the differences among EU member states in economic development and welfare provision have increased and, therefore, also has the potential for welfare migration. While numbers of inner-EU mobility were traditionally low, they have been increasing in recent times. Moreover, the integration process has always been characterised by judicialisation, where important impetus stems from rulings of the European Court of Justice (ECJ). Its citizenship jurisprudence has strived to create direct bonds between EU citizens and the Union, by strengthening equal rights not only for those employed, but also for economically inactive EU citizens. Rulings of the Court created significant adjustment pressures for member states' social policies. While the Court has recently strengthened member states to potentially restrict social benefits for economically inactive EU citizens and newly arrived jobseekers, the question of who qualifies as a worker has become all the more important - with ECJ case law mandating that this status and, accordingly, full equal treatment may apply for those just working $5.5 \mathrm{~h}$ a week, as the prerequisite is that work is not only 'marginal and ancillary'. However, on comparison, national implementation of this judge-made concept differs widely (O'Brien et al. 2016).

In general, EU citizens move to other member states in order to work. As most are of working age, they in general contribute more to their host countries than they consume in the form of public services and benefits (Dustmann et al. 2010; Martinsen and Pons Rotger 2017). Yet, broad non-discrimination rules can also be subject to exploitation, either in terms of setting individual incentives for benefit support, as may happen, for instance, for students studying in another member state, but in part also for organised welfare abuses. There is limited evidence for welfare migration or welfare abuses, but even low absolute numbers carry great risks of being politicised. As this may harm the legitimacy of the political system of the EU and its member states, concerns have to be taken seriously. Next to the British upheaval, we do in fact observe reforms of social rights and residence rules targeting EU citizens in several member states. Responses are, however, diverse, as the type of welfare state, administrative cooperation, the political economy of labour 
markets, but also the conditions in the home country, and language similarities all play a role.

The collection analyses a crucial topic for modern European societies: how to reconcile free movement rights and equal treatment on one side with the traditional closure of the welfare state on the other side. As rights to non-discriminatory access to social benefits for EU citizens are much settled by case law, the collection also contributes to a further understanding of the way case law of the European Court of Justice structures national policies as well as administrative practice. The collection brings together the normative, legal and political content and contestation of free movement and welfare equal treatment. It assembles articles discussing the normative and legal basis of EU citizenship, free movement and cross-border access to social benefits; the politicised discussion of welfare migration in the media and its impact on the jurisprudence of the European Court of Justice; as well as contributions examining the theoretical and empirical nexus between Union free movement and its reconciliation with the welfare state's need for closure.

\section{Legal framework}

The four freedoms, covering goods, services, persons (comprising the free movement of workers and of establishment), and capital are the building blocks of the single market, and with it of one of the central achievements of European integration. Right from the start, the free movement of workers became relevant, with Italy being interested in the export of workers, and the other member states being able to take in surplus labour into their growing economies. Already in 1958, regulations No. 3 and 4 set down first rules for the coordination of social security for migrant workers. It is on this basis that the current regime of regulations 883/04 (formerly 1408/71) and 492/2011 (formerly 1612/68) evolved. As member states did not want to relinquish the responsibility for their welfare systems, the EU only coordinates the responsibilities and rights. In general, the regulations establish the principle of 'lex loci laboris', implying that a person is covered by the system where he or she works (Christensen and Malmstedt 2000). If country of work and residence are not the same, the latter has some residual responsibilities. By contrast, the country of residence is responsible for those that are economically inactive. Whereas the contributory benefits of regulation 883/04 are portable, social assistance benefits are not.

The revisions of these regulations on the coordination of social security reflect not only the changing world of labour and of welfare, but also the importance of the ECJ rulings in this area. As the arbiter not only for the interpretation of the regulations, but also of the free movement right in the Treaty, the Court has repeatedly expanded rights, which member states were eager to restrict for EU workers. Importantly, when the ECJ interprets 
the Treaty, this interpretation becomes part of the Treaty, and thereby influences subsequent legislation (Schmidt 2018). In this way, the Court set out in the 1980s that the privileged status of the free movement of workers applies as soon as work is not 'only marginal and ancillary', so that it covers also those persons that work few hours and cannot meet the needs of their subsistence (C-53/81 Levin). At the same time, EU member states have also sought to use legislation to contain cross-border welfare where the Court's jurisprudence left them with room for manoeuvre (see the amendments of regulation $1408 / 71$ by regulation $27 / 93$ and $1247 / 92$. See also the citizenship directive's Article 24(2); Martinsen 2015).

EU citizenship was introduced with the Treaty of Maastricht. Originally, this was more of a symbolic addition, as member states clearly did not want to renounce the sovereignty over their citizenship regimes. Article 21 TFEU grants 'the right to move and reside freely within the territory of the Member States, subject to the limitations and conditions laid down in this Treaty and by the measures adopted to give it effect.' Despite the explicit reference to secondary law, from the late 1990s onwards, the Court has shaped the EU citizenship regime with its judgments. Famously, in Grzelczyk (C-184/99) the Court ruled: 'Union citizenship is destined to be the fundamental status of nationals of the Member States' (para 31). The citizenship directive that was agreed shortly before the Eastern enlargement of 2004 provides the secondary law to these rights. During the first three months, EU citizens can freely reside in other member states. After five years of legal residence, they have the right to permanent residence and to be treated equally with the hosting member states' own nationals. For those in between these thresholds, the directive failed to provide clear rules. On the one hand, citizens have to be financially self-sufficient and have their own health insurance. On the other hand, member states cannot automatically expel those in need (Article 14(3)). This reflects the existing case law of the Court that the EU legislator could not overrule but aimed to tame by adding preconditions (Wasserfallen 2010). Thus, in Grzelczyk benefits were granted after three years, and the Court generally emphasized that member states needed to assess eligibility individually, with view to the integration into the host member state. However, at the same time, the citizenship directive specified that member states were not obliged to pay study grants to EU citizens who are not workers, self-employed or their family members before permanent residence, i.e., five years of residence (Article 24(2)). The judicial and political reading of the scope and limits of EU rules on cross border welfare appear to be an ongoing battle.

As we will see in the contributions in this collection, the existing legal uncertainty relating to the (un)equal treatment of EU citizens' resulted in many court cases and quite diverse approaches in EU member states, depending on the precise shape of their welfare system, political and administrative responses, access to domestic courts, and the willingness of judges to take up 
European law and possibly refer cases to the ECJ. Alongside the growing political contention as to welfare migration, the ECJ appears to have stopped its expansion of rights since late 2014, giving more scope to member states to protect their welfare systems from those entering member states and not being economically active (C-333/13 Dano).

\section{The role of the ECJ: normative assessment and empirical analysis}

The crucial role played by the ECJ in interpreting and re-balancing free movement and equal treatment is a recurrent topic across the contributions to this collection. The Court has long been hailed as an 'engine of integration' or criticised for 'judicial activism' and its recent turn on EU citizenship is enlightening for this debate, both from a normative and from an empirical-analytical perspective.

While the ECJ's ability to promote 'integration through law' is often implicitly endorsed by EU scholars, it has also triggered significant normative debate about the right balance of judicial and political decision-making in the EU's political system. The Court's interpretation of EU citizens' individual rights is at the core of these debates. On one side, judicialisation is regarded as essential for protecting and extending individual rights and, thus, for promoting liberal democracy in the EU (Kelemen 2013). On the other side, due to an asymmetry between judicial and political decision-making, the EU is said to be biased towards individual rights and to undermine the political autonomy and republican legitimacy of its member states (Scharpf 2009). Given the high hurdles for changing 'over-constitutionalised' (Grimm 2015) EU Treaty law politically, much depends on European judges themselves and what particular balance they strike between EU citizens' individual rights and national political autonomy, e.g., regarding welfare policies.

The ECJ's case law on EU citizenship is commented upon extensively by EU legal scholars in terms of legal coherence and with regard to its broader desirability - the latter, however, often without the underlying normative theory being made explicit. In their contribution to this collection, Bellamy and Lacey (2018) systematise and discuss different normative accounts of the relationship between European and national citizenship as well as their implications for welfare rights. Transnationalists and supranationalists, they argue, ultimately aim at transforming national into Union citizenship in order to overcome problems of arbitrary exclusion of non-nationals. By contrast, Bellamy and Lacey emphasise the parallel problem of arbitrary inclusion of nonnationals, for instance, with regard to non-contributory welfare benefits, and insist on the continued relevance of national citizenship and national political communities. They propose a demoicratic approach, intended to preserve the 'advantages of national citizenship while overcoming many of its 
disadvantages' (Bellamy and Lacey 2018) for non-nationals with a perspective to 'stakeholdership' abroad. For this the 'willingness and capacity to contribute to the socioeconomic fabric of the receiving state' (Bellamy and Lacey 2018 ) is decisive. Their approach provides a normative yardstick to critically assess the Court's teleological jurisprudence, proclaiming EU citizenship to be 'destined to be the fundamental status of nationals of the member states' (Grzelczyk), while showing greater deference to a complementary conception of EU citizenship and to the political intentions behind EU secondary legislation.

From an empirical-analytical perspective, the Court's recent turn on citizenship is equally interesting as it offers new insights to an established debate around the question: to what extent is the ECJ independent from or responsive to political influence? On the one hand, strong arguments have been forwarded why the ECJ's independence from political interference even exceeds that of many domestic constitutional courts (Kelemen 2012). On the other hand, recent large-scale empirical studies have demonstrated that the Court responds to member state political signals such as threats of legislative override or domestic non-compliance (for an overview, see Blauberger and Schmidt 2017). And yet, both lines of argument provide only partial explanations for the Courts ability, first, to extend EU citizenship rights far beyond member states' original intention and, more recently, for its restrictive turn (for discussion of the ECJ's role in policy-making see Martinsen 2015; Schmidt 2018).

The contribution by Blauberger et al. (2018) sets out to investigate empirically the ECJ's turnaround on EU citizenship. According to the dominant view among EU legal scholars (see the contributions to Thym 2018; for an opposed view, see Davies 2018), the Court has indeed shifted its interpretation of EU citizenship in recent years, although the underlying legal basis has remained unchanged. Blauberger et al. argue that threats of legislative override or noncompliance cannot sufficiently account for this judicial turnaround. Focusing qualitatively on the citizenship cases - while the literature on member states' political signals uses quantitative data - they can show that member states' written observations to the Court were always critical of the extension of citizenship rights. To explain the recent change in jurisprudence, it is therefore necessary to take into account public opinion and politicisation processes. On the basis of an extensive newspaper analysis, they show that 'judges read their morning papers' and answered with more restrictive jurisprudence to the increased political contestation of equal rights to non-contributory social benefits for newly settled EU citizens.

From the legal side, Davies (2018) argues that it is not so much the Court that changed but the cases that have been brought to it. The expansive case law on citizenship rights that evolved since the late 1990s, he argues, all involved EU citizens in need that were well-integrated into their host societies, 
and were well-deserving of solidarity of the host society. Many of the new cases, in contrast, aim to test the extent of this solidarity in his reading. They differ significantly from those earlier citizenship cases. Rather than asking for solidarity for EU citizens that had made every effort in their host societies, the recent cases confront the ECJ with EU citizens seeking support without having established any 'real link' (Vatsouras C-22-23/08). Davies, therefore, does not share the prevailing opinion in European law that the Court altered its jurisprudence. To him, we witness a normal development. Having established the doctrine, increasingly, outlier cases reach the Court, giving it the opportunity to clarify the bounds of EU citizenship rights.

\section{Politicisation on the rise}

Free movement of persons and cross-border welfare in the EU have become increasingly salient issues in national public debates. Already on the agenda during the European constitution referenda campaigns in the Netherlands and France in 2005 (Hemerijck 2013), politicisation came to a dramatic increase in some member states 2013-2015 - with 'welfare tourism' being increasingly part of the political vocabulary (Blauberger et al. 2018). Existing research has come up with different explanations as to the driving factors of politicisation. Transfer of authority, party incentives or the lack thereof, competing party officials or institutional misfit between EU principles and national institutions are among existing explanations as to what drives politicisation and why it varies across member states (de Wilde et al. 2016; Grande and Hutter 2016; Green-Pedersen 2012).

Comparing politicisation of free movement of persons in Germany and the UK, Roos (2018) recently identified different party responses in the two member states. Whereas mainstream parties in Germany did restrict EU citizens' access to welfare benefits, they never joined in on a general discourse, questioning the basic principles of freedom of movement. By contrast, in the UK, the governing conservative party and UKIP as its right-wing challenger actively promoted such a negative discourse, which escalated politicisation. When it comes to the consequences of politicisation, scholars seem to share the view that politicisation constrains a linear and forward move of European integration, but differs on whether it will lead to disintegration as such (Hooghe and Marks 2009) or more differentiated forms of integration (Schimmelfennig et al. 2015).

Two contributions to this collection analyse the individual attitudes and domestic institutions in the politicisation of free movement. Zooming in on EU citizens views on free movement of workers, Ferrera and Pellegata (2018) compare citizens' attitudes in France, Germany, Italy, Poland, Spain and Sweden by means of a novel survey analysis. Their contribution moves beyond broader socio-economic factors and, for the first time, brings in 
how individual factors may account for public support of national closure. Their analysis shows that citizens' socio-economic attachment, i.e., their market and status positions can only explain a small part of the attitudinal differences identified. Instead, political orientations, situational and relational experiences filter the impact of market and status positions. Ferrera and Pellegata show that although the 'losers' of globalisation are more likely to opt for the closure of national communities, political orientation and a range of situational and relational factors (such as experiences of intertemporal relative deprivation, cross-national contacts or associational membership) may contain or push labour chauvinist attitudes. They conclude that whereas pro-closure attitudes constitute an alarming destabilising factor for the integration process, the role played by situational and relational factors indicate that the 'lure of souverainisme' can be resisted, depending on the political will to do so.

The contribution of Ruhs and Palme (2018) adds an institutional explanation to politicisation. They argue that we need to move beyond analysing the role of actors, such as populist political parties and the media, and take national institutions into consideration if we want to understand political contestation to free movement. National labour markets and welfare state institutions are likely to affect the development of policy positions on free movement directly, or indirectly via inter-relationships with normative attitudes as well as the characteristics of EU labour immigration. Different national welfare models and policies can be expected to be associated with different underlying principles of redistribution and associated normative attitudes about who, should get access to welfare benefits and under what conditions (e.g., based on 'need', 'prior contribution', 'universal access' etc.). At the same time, there is a widespread and common view among the populations of EU member states that 'reciprocity' should be a guiding principle in the provision of welfare benefits for immigrants. Ruhs and Palme argue that demands for restricting social rights for EU workers are likely to be greater in countries and for specific welfare policies - whose underlying principles and associated normative attitudes clash with the reciprocity norm. For liberal market economies with high EU immigration into low-waged jobs, Ruhs and Palme expect considerable interaction effects leading to restrictive policy responses. Their contribution, thus, highlights the many determinants of member states' institutions and interaction that matter for - and differentiate - the domestic responses to intra-European migration, which should also impact on politicisation.

\section{Welfare states between resilience and retrenchment}

How are member states faring in a regime facilitating access of EU migrants to their traditionally closed welfare states? While some have welcomed the 
Court's expansive citizenship jurisprudence as a bold step towards making Europe more social (Caporaso and Tarrow 2009), others have warned against undermining national welfare systems (Höpner and Schäfer 2012: 448). And yet, not that much is known empirically, how the 'experiment' (Geddes and Hadj-Abdou 2016: 222) of open borders and national solidarity is developing. Also, on a more general level, Europeanisation research has long neglected the domestic effects of Court jurisprudence (Treib 2014: 13) and only recently researchers have begun to pay greater attention to its implementation by national administrations (Dörrenbächer 2017). Does the increasing politicisation translate into reform pressures of highly developed welfare states to continue financing their benefits?

Kramer et al. (2018) present a comparative analysis of the Netherlands and Denmark regarding EU citizens' access to non-contributory benefits. They trace several domestic reforms, aiming to 'quarantining' EU-citizens' access to benefits. Member states have, thus, managed to shape their welfare systems in a more restrictive way, thereby foreclosing avenues for EU citizens to claim benefits. The 'experiment' of free movement in their analysis can be combined with the welfare state by systematically using the leeway that ECJ case law gives to let EU citizens first 'earn' their citizenship rights. By singling out those policy instruments that allow member states to postpone equal rights, the highly developed welfare state can survive the consequences of free movement in a heterogeneous Union and, apart from rare cases, avoid broader welfare retrenchment.

Schenk and Schmidt (2018) analyse one of the most prominent instances where equal treatment of EU citizens was perceived as a risk in terms of future welfare provision - the case of German medical students at Austrian universities. Austria, in a similar situation to Belgium neighbouring France, had problems to ensure the training of a sufficient number of medical doctors, as its universities were filled up by Germans, who returned to their home country after obtaining the medical degree. After many years of conflict, in May 2017, the Commission finally agreed that Austria could keep its quota system in order to assure sufficient numbers of medical doctors. Non-discriminatory access to university here threatened public health as a public-policy goal, allowing restricting freedom of movement. The example shows that under adverse conditions - a small country with tuition-free university sharing the same language with a larger neighbour - high mobility may indeed undermine welfare. Yet, the comparison with similar pressure to open up financial study support for students shows that in this case the social entitlements were complex enough with their many preconditions, to give member states sufficient scope in the handling to make equal access for EU citizens difficult - mirroring the finding of quarantining of Kramer et al. 


\section{Conclusion}

The free movement of workers has been at the origin of European integration and, more than 60 years after its introduction, it features prominently in debates about the future of Europe. On the one hand, 'the free movement of EU citizens who can live, work, study and do business anywhere in the EU' is valued highly by ordinary citizens ${ }^{1}$, and celebrated as one of the major achievements of integration. On the other hand, some of the most vociferous expressions of anti-EU sentiment have revolved around intra-EU migration and cross-border access to national welfare systems, not the least during the Brexit campaign.

By analysing free movement and equal treatment from multiple perspectives, this collection adds to several core debates in current EU studies: e.g., on the (im)balance between liberal market freedoms and social protection, on the relative power of judicial and political decision-making in the EU, on the gap between abstract EU legal principles and member state implementation on the ground, and on the differences between actual problem pressure and patterns of politicisation. While none of these debates will be settled by this collection, the individual contributions raise the level of debate by presenting and moving beyond the state of the art in their respective fields.

Imminent significant changes are unlikely, as the welfare state stays largely resilient, also due to measures of quarantining EU citizens and enhanced administrative controls. Given the existing institutional diversity among member states, the implications of free movement are much more finegrained than earlier analyses assumed. Where parts of EU citizens are highly mobile, like students, pressure on welfare provision may rise accordingly. Normatively, the question of the extent of solidarity towards EU citizens and of stakeholdership remains important and is likely to lead to continuing political and academic debates. How politicisation plays out, however, is no automatism but depends on individuals' experiences and networks. Given the pressures, and the room for manoeuvre, in the continuous interplay between law and politics in the EU polity, much may depend on that the judges continue to read their morning papers, to prevent political disintegration.

\section{Note}

1. See Eurobarometer 88, 2017: http://www.poci-compete2020.pt/admin/images/ Standard_Eurobarometer_88_UE_dez-2017.pdf

\section{Acknowledgements}

We would like to thank the editors of JEPP for their support of this collection, and the anonymous reviewers as well as the participants of the November 2017 workshop in Bremen for their feedback. Britta Plote and Fabian Taute provided very valuable assistance. The research for this article was part of a Norface-funded project, TransJudFare, Grant no. 462-13-009. 


\section{Disclosure statement}

No potential conflict of interest was reported by the authors.

\section{Funding}

The research for this article was part of a Norface Welfare State Futures (WSF)-funded project, TransJudFare [grant number 462-13-009].

\section{Notes on contributors}

Susanne K. Schmidt is Professor of political science at the University of Bremen (https:// orcid.org/0000-0001-7931-9935).

Michael Blauberger is Associate Professor at the University of Salzburg (https://orcid. org/0000-0002-3581-400X).

Dorte Sindbjerg Martinsen is Professor at the University of Copenhagen (https://orcid. org/0000-0002-2113-0950).

\section{References}

Bellamy, R. and Lacey, J. (2018) 'Balancing the rights and duties of European and national citizens: a demoicratic approach', Journal of European Public Policy, doi:10. 1080/13501763.2018.1488885

Blauberger, M. and Schmidt, S.K. (2017) 'The European court of justice and its political impact', West European Politics 40(4): 907-18.

Blauberger, M., et al. (2018) 'ECJ judges read the morning papers. Explaining the turnaround of European citizenship jurisprudence', Journal of European Public Policy, doi:10.1080/13501763.2018.1488880

Caporaso, J.A. and Tarrow, S. (2009) 'Polanyi in Brussels: supranational institutions and the transnational embedding of markets', International Organization 63(4): 593-620.

Christensen, A. and Malmstedt, M. (2000) 'Lex loci laboris versus Lex loci domicilii - an inquiry into the normative foundations of European social security Law', European Journal of Social Security 2(1): 69-111.

Davies, G. (2018) 'Has the court changed, or have the cases? The deservingness of litigants as an element in court of justice adjudication', Journal of European Public Policy, doi:10.1080/13501763.2018.1488881

de Wilde, P., Leupold, A. and Schmidtke, H. (2016) 'Introduction: the differentiated politicisation of European governance', West European Politics 39(1): 3-22.

Dörrenbächer, N. (2017) 'Europe at the frontline: analysing street-level motivations for the use of European Union migration law', Journal of European Public Policy 24(9): 1328-47.

Dustmann, C., Frattini, T. and Halls, C. (2010) 'Assessing the fiscal costs and benefits of A8 migration to the UK', Fiscal Studies 31(1): 1-41.

Ferrera, M. and Pellegata, A. (2018) 'Worker mobility under attack? Explaining labour market chauvinism in the EU', Journal of European Public Policy, doi:10.1080/ 13501763.2018 .1488886

Geddes, A. and Hadj-Abdou, L. (2016) '12 an unstable equilibrium: freedom of movement and the welfare state in the European Union', in G. Freeman and N. Mirilovic (eds.), Handbook on Migration and Social Policy, Cheltenham: Edward Elgar Publishers, pp. 222-38. 
Grande, E. and Hutter, S. (2016) 'Beyond authority transfer: explaining the politicisation of Europe', West European Politics 39(1): 23-43.

Green-Pedersen, C. (2012) 'A giant fast asleep? Party incentives and the politicisation of European integration', Political Studies 60(1): 115-30.

Grimm, D. (2015) 'The democratic costs of constitutionalisation: the European case', European Law Journal 21(4): 460-73.

Hemerijck, A. (2013) Changing Welfare States, Oxford: Oxford University Press.

Hooghe, L. and Marks, G. (2009) 'A postfunctionalist theory of european integration: from permissive consensus to constraining dissensus', British Journal of Political Science 39(1): 1-23.

Höpner, M. and Schäfer, A. (2012) 'Embeddedness and regional integration: waiting for Polanyi in a Hayekian setting', International Organization 66(3): 429-55.

Kelemen, R.D. (2012) 'The political foundations of judicial independence in the European Union', Journal of European Public Policy 19(1): 43-58.

Kelemen, R.D. (2013) 'Judicialisation, democracy and European integration', Representation 49(3): 295-308.

Kramer, D., van Hooren, F., and Thierry, J.S. (2018) 'Responding to free movement: quarantining mobile union citizens in european welfare states', Journal of European Public Policy, doi:10.1080/13501763.2018.1488882

Martinsen, D.S. (2015) An Ever More Powerful Court? The Political Constraints of Legal Integration in the European Union, Oxford: Oxford University Press.

Martinsen, D.S. and Pons Rotger, G. (2017) 'The fiscal impact of EU immigration on the tax-financed welfare state: testing the 'welfare burden'thesis', European Union Politics 18(4): 620-39.

O'Brien, C., Spaventa, E. and De Corninck, J. (2016) 'Comparative report 2015-the concept of worker under Article 45 TFEU and certain non-standard forms of employment'.

Roos, C. (2018) 'The (de-) politicization of EU freedom of movement: political parties, opportunities, and policy framing in Germany and the UK', Comparative European Politics: 1-20, doi:10.1057/s41295-018-0118-1

Ruhs, M. and Palme, J. (2018) 'Institutional contexts of political conflicts around free movement in the European Union: a theoretical analysis', Journal of European Public Policy, doi:10.1080/13501763.2018.1488883

Scharpf, F.W. (2009) 'Legitimacy in the multilevel European polity', European Political Science Review 1(2): 173-204.

Schenk, A. and Schmidt, S.K. (2018) 'Failing on the social dimension: judicial law-making and student mobility in the EU', Journal of European Public Policy, doi:10.1080/ 13501763.2018.1488884

Schimmelfennig, F., Leuffen, D. and Rittberger, B. (2015) 'The European Union as a system of differentiated integration: interdependence, politicization and differentiation', Journal of European Public Policy 22(6): 764-82.

Schmidt, S.K. (2018) The European Court of Justice and the Policy Process: The Shadow of Case Law, Oxford: Oxford University Press.

Thym, D. (ed) (2018) Questioning EU Citizenship. Judges and the Limits of Free Movement and Solidarity in the EU, London: Hart Publishing.

Treib, O. (2014) 'Implementing and complying with EU Governance outputs', Living Reviews in European Governance 9(1): 1-47.

Wasserfallen, F. (2010) 'The judiciary as legislator? How the European court of justice shapes policy-making in the European Union', Journal of European Public Policy 17 (8): 1128-1146. 